\title{
Assessing the effect of concomitant administration of artemether-lumefantrine and ciprofloxacin on some cardiac parameters in Wistar rats: "The remedial role of vitamin E"
}

Jessie Idongesit Ndem 1, ${ }^{*}$, Pamela Udoh Sylvanus ${ }^{1}$, Utibe Evans Bassey ${ }^{2}$, Blessing Obinaju Effiong ${ }^{3}$ and Efosa Godwin Ewere ${ }^{1}$

${ }^{1}$ Department of Biochemistry, Faculty of Science, University of Uyo, Uyo, Akwa Ibom State, Nigeria.

${ }^{2}$ Department of Biochemistry, Faculty of Basic Medical Sciences, PAMO University of Medical Sciences, Port Harcourt, Rivers State, Nigeria.

${ }^{3}$ Department of Medical Biochemistry, Faculty of Basic Medical Sciences, University of Uyo, Uyo, Akwa Ibom State, Nigeria.

GSC Biological and Pharmaceutical Sciences, 2021, 17(01), 094-104

Publication history: Received on 13 August 2021; revised on 04 October 2021; accepted on 06 October 2021

Article DOI: https://doi.org/10.30574/gscbps.2021.17.1.0276

\begin{abstract}
The effect of Vitamin E on some cardiac parameters following concomitant administration of artemether-lumefantrine (AL) and ciprofloxacin in male Wistar rats was investigated. Thirty-five male Wistar rats weighing between $190-220$ $\mathrm{g}$, used for the study were randomly divided into seven groups of five animals each. Group I served as the control. Group II - VII were administered; $8 \mathrm{mg} / \mathrm{kg}$ body weight (bw) of AL; $7.14 \mathrm{mg} / \mathrm{kg}$ bw of Ciprofloxacin; $8 \mathrm{mg} / \mathrm{kg}$ bw of AL +7.14 $\mathrm{mg} / \mathrm{kg}$ bw of Ciprofloxacin; $8 \mathrm{mg} / \mathrm{kg}$ bw of AL + 8.57 IU of Vitamin E; $7.14 \mathrm{mg} / \mathrm{kg}$ bw of Ciprofloxacin + 8.57 IU of Vitamin $\mathrm{E}$; and $8 \mathrm{mg} / \mathrm{kg}$ bw of AL $+7.14 \mathrm{mg} / \mathrm{kg}$ bw of Ciprofloxacin $+8.57 \mathrm{IU}$ of Vitamin E respectively. All the drugs were administered at their therapeutic regimen. Some cardiac parameters investigated include lipid profile, Troponin I, Troponin T, Creatine kinase, Lactate dehydrogenase and aspartate aminotransferase. The result showed significant ( $p$ $<0.05)$ increase in all the parameters of cardiac function when treatment groups were compared with control. The observed increase in cardiac indices were however significantly $(p<0.05)$ ameliorated in Groups V, VII and VII which were co-administered with Vitamin E compared with Groups II, III and IV which received the test drugs independently. The weights of the heart tissues showed the same trend with the parameters of cardiac function assessed and upon administration of vitamin E. The results obtained suggest the antioxidative role of vitamin $\mathrm{E}$ in alleviating the negative effects induced by artemether-lumefantrine and ciprofloxacin combination treatment, which may be from the impact of free radicals that may have been generated by the combined drugs.
\end{abstract}

Keywords: Malaria; Artemether-lumefantrine; Ciprofloxacin; Vitamin E; Cardiac Function

\section{Introduction}

Malaria remains the World's most important tropical parasitic disease with regards to mortality and morbidity [1]. It is an important public health disease in both tropical and sub-tropical countries in Africa with its major incidence occurring in rainy season [2]. It is life-threatening disease caused by protozoan parasites of the genus Plasmodium and transmitted through the bites of infected female Anopheles mosquitoes [3]. In Africa, P. falciparum is the major cause of the most severe form of malaria and accounts for over $60 \%$ of outpatient visits and $30 \%$ of hospital admission in Nigeria [4] and it is also resistant to the readily available over- the -counter anti- malarial drugs.

\footnotetext{
${ }^{*}$ Corresponding author: Jessie Idongesit Ndem

Department of Biochemistry, Faculty of Science, University of Uyo, Uyo, Akwa Ibom State, Nigeria. 
Diverse therapeutic approaches have been in practice over time to manage malaria in various parts of the world with main focus on the elimination of the vector and the development of antimalarial drugs especially against the resistance $P$. falciparum. Due to the increasing resistance of malaria parasite to older anti-malarial drugs, such as chloroquine and sulphadoxine-pyrimethamine, artemisinin-based combination therapies (ACTs) have been adopted worldwide for the treatment of uncomplicated malaria [5]. Artemether-lumefantrine is one of such ACTs and it is most commonly used in Sub-Saharan Africa, Nigeria in particular, for the treatment of malaria. Artemether-lumefantrine like other artemisinin derivatives, causes malaria parasite death through the generation of free radicals, depletes the antioxidant defense system causing oxidative stress [6, 7]

Fluoroquinolones, especially ciprofloxacin are known for the treatment of typhoid due to the development of resistance to other antibiotics [8]. These drugs have been proven to be very effective against the pathogenic micro-organisms. However, the toxicities of fluoroquinolones have been reported independently, even at normal therapeutic doses [9]. Ciprofloxacin is one of the most commonly used antibiotics for the treatment of typhoid fever in Nigeria and it is also readily available as an over-the-counter medication.

There is a report that malaria is over-diagnosed and over-treated in some endemic areas of the world thereby increasing further risk of drug induced toxicity [10]. Co-infection of malaria parasite and Salmonella species is also common in Nigeria, and anti-malarial drugs in combination with antibiotics especially ciprofloxacin are frequently administered concomitantly without adequate laboratory diagnoses for both diseases. There is a report that co-administration of artemisinin/artemisinin derivatives and ciprofloxacin is a common practice in the South-South region of Nigeria in the treatment of malaria [11]. Clinically, important interactions may occur between antimalarial drugs and ciprofloxacin compromising or potentiating the treatment of either infection.

Concurrent or irrational treatment of malaria with antimalarial and antibiotic may have some public health implications such as increasing surge of drug resistance and exposure of individuals to side effects of antibiotic [12]. Multiple drug administration causes some harmful effects generally and has critical impact on body organs [13]. An interaction is said to occur when the effects of one drug are altered by the co-administration of another drug, herbal medicine, food, drink or other environmental chemical agents [14]. The altered effects can be physiological and / or pharmacological [15]. This study was designed to evaluate the effect of concomitant administration of artemether-lumefantrine and Ciprofloxacin on some cardiac parameters and also assess if vitamin E would remediate the observed effects in male Wistar rats.

\section{Methodology}

\subsection{Drugs}

Artemether-lumefantrine (Coartem, $20 \mathrm{mg} / 120 \mathrm{mg}$ ) manufactured by Novartis Pharmaceutical Corporation Switzerland, ciprofloxacin (USP $500 \mathrm{mg}$ ) produced by Micro Labs Limited - India and vitamin E (d-alpha tocopheryl Acetate) produced by Mega Life Sciences Public Company Limited - Thailand) were purchased from a commercial pharmaceutical store (Pharmablaze Pharmacy) in Uyo, Akwa Ibom State, Nigeria. The vitamin E (800 IU) was aspirated into a syringe and then reconstituted with measured amount of corn oil prior to daily administration.

\subsection{Research Design}

Thirty-five (35) mature male Wistar rats weighing between 190 - 220 g were used for the study. They were obtained from the Animal House, Department of Pharmacology and Toxicology, University of Uyo, Uyo, Akwa Ibom State, Nigeria. The animals were acclimatized for two weeks prior to the commencement of drugs administration. They were kept in well ventilated cages and were fed with standard rat pellets and water ad libitum throughout the experimental period. The Animals were randomly divided into seven groups of five $(n=5)$ animals each and administered therapeutic regimen of the drugs; artemether-lumefantrine was administered for 3 days, ciprofloxacin for 5 day and Vitamin $\mathrm{E}$ for 7 days. The dosage given was equivalent to that for a $70 \mathrm{~kg}$ man and calculated in $\mathrm{mg} / \mathrm{kg}$ body weights of the experimental animals. The experimental design is as follow:

- Group I: Control

- Group II: Artemether-lumefantrine (8 mg/kg body weight, twice daily).

- Group III: Ciprofloxacin (7.14 mg/kg body weight, twice daily).

- Group IV: Artemether-lumefantrine ( $8 \mathrm{mg} / \mathrm{kg}$ body weight) and ciprofloxacin (7.14 mg/kg body weight) twice daily. 
- Group V: Artemether-lumefantrine ( $8 \mathrm{mg} / \mathrm{kg}$ body weight, twice daily) and Vitamin E (8.57 IU per body weight, daily).

- Group VI: Ciprofloxacin (7.14 mg/kg body weight, twice daily) and Vitamin E (8.57 IU per body weight, daily).

- Group VII: Artemether-lumefantrine ( $8 \mathrm{mg} / \mathrm{kg}$ body weight, twice daily), ciprofloxacin $(7.14 \mathrm{mg} / \mathrm{kg}$ body weight, twice daily) and Vitamin E (8.57 IU per body weight, daily).

\subsection{Collection and Treatment of Samples}

At the end of the experimental period, the animals were anaesthetized by chloroform inhalation in a closed chamber and thereafter, sacrificed. Blood sample was collected by cardiac puncture into plain sample bottle and centrifuged at $4000 \mathrm{rpm}$ for 15 minutes to obtain the serum. The serum was carefully collected with the used syringe and needle into plain sample bottles and used for analyses. The heart tissues were also harvested and weighed.

\subsection{Determination of Biochemical Parameters}

Serum Lipid Profile including triglycerides, total cholesterol, high-density lipoprotein cholesterol, were assayed using Fortress Assay Kit. Very low-density lipoprotein cholesterol and Low-density lipoprotein cholesterol were calculated using Friedwald's formula [16]. The activities of creatinine kinase, lactate dehydrogenase and AST were assayed using reagents from Fortress Assay Kits. The concentrations of Troponin I and T were assayed using enzyme-linked immunosorbent assay method with ELISA Kits supplied by Calbiotech Inc. CA. The assay procedures described by the kits' leaflet were employed accurately in the assay process.

\subsection{Statistical Analysis}

Data obtained were subjected to one-way analysis of variance (ANOVA) and compared using Newman Keuls Multiple Comparison Test. Results are presented as mean \pm standard deviation (SD). Differences between experimental groups are considered statistically significant at $\mathrm{p}<0.05$.

\section{Results}

Serum lipid profile of male Wistar rats administered artemether-lumefantrine, Ciprofloxacin and Vitamin E is presented in Table 1. The administration of artemether-lumefantrine or Ciprofloxacin singly, increased the concentrations of total cholesterol, triglyceride, low density lipoprotein and very low-density lipoprotein when compared to the control. Significantly increased concentrations of serum TC, TG, LDL-c and VLDL-c were also observed in artemetherlumefantrine with ciprofloxacin treated group when compared with the control group $(p<0.05)$. Furthermore, the administration of vitamin $\mathrm{E}$ with artemether-lumefantrine or ciprofloxacin and their combination was observed to significantly decrease the concentrations of total cholesterol, triglyceride, LDL-c and VLDL-c when compared to the administration of artemether-lumefantrine or Ciprofloxacin and their combination respectively. The changes in the concentration of high-density lipoprotein were not significantly different between the treatment groups and the control except for Group IV which was significantly lower than the control.

Table 2 shows the concentrations of Troponin I and Troponin T, activities of creatine kinase, lactate dehydrogenase and aspartate aminotransferase in the present study. The concentrations of Troponin I and $\mathrm{T}$ as well as activities of creatinine kinase, lactate dehydrogenase and aspartate aminotransferase were also observed to increase following the administration of artemether-lumefantrine, ciprofloxacin and their combination when compared to the control group. However, significant $(\mathrm{p}<0.05)$ difference was only observed in the group which received artemether-lumefantrine and ciprofloxacin concomitantly. The administration of vitamin E with artemether-lumefantrine or ciprofloxacin or combination of artemether-lumefantrine and ciprofloxacin significantly reduced the activities of the enzymes and concentrations of troponins when compared to respective individual treatments.

The weight of the heart tissues treated are presented in Table 3. There were significant $(p<0.05)$ changes in the weight of the heart tissues when the treatment groups were compared with the control group. The results followed the same pattern with the other parameters assayed. 
Table 1 Serum Lipid Profile of Male Wistar Rats Administered Artemether-Lumefantrine, Ciprofloxacin and Vitamin E

\begin{tabular}{|c|c|c|c|c|c|}
\hline Grouping/Dosage & $\begin{array}{l}\text { Total cholesterol } \\
\text { (mg/dl) }\end{array}$ & $\begin{array}{l}\text { Triglycerides } \\
\text { (mg/dl) }\end{array}$ & $\begin{array}{l}\text { HDL-Cholesterol } \\
\text { (mg/dl) }\end{array}$ & $\begin{array}{l}\text { VLDL-Cholesterol } \\
\qquad(\mathrm{mg} / \mathrm{dl})\end{array}$ & $\begin{array}{l}\text { LDL-Cholesterol } \\
\text { (mg/dl) }\end{array}$ \\
\hline $\begin{array}{l}\text { Group I } \\
\text { Normal control }\end{array}$ & $82.72 \pm 3.91$ & $69.56 \pm 2.22$ & $28.87 \pm 1.42$ & $13.91 \pm 0.44$ & $39.93 \pm 4.94$ \\
\hline $\begin{array}{l}\text { Group II } \\
8 \mathrm{mg} / \mathrm{kg} / \mathrm{bw} \mathrm{AL}\end{array}$ & $110.70 \pm 6.92^{*}$ & $89.14 \pm 1.79^{*}$ & $26.33 \pm 2.75^{*}$ & $17.83 \pm 0.36^{*}$ & $66.56 \pm 9.24^{*}$ \\
\hline $\begin{array}{l}\text { Group III } \\
7.14 \mathrm{mg} / \mathrm{kg} / \mathrm{bw} \text { Cipro }\end{array}$ & $119.50 \pm 2.28^{*}$ & $93.34 \pm 1.80^{*}$ & $26.26 \pm 5.36^{*}$ & $18.67 \pm 0.36^{*}$ & $74.52 \pm 2.81^{*}$ \\
\hline $\begin{array}{l}\text { Group IV } \\
8 \mathrm{mg} / \mathrm{kg} \mathrm{AL}+7.14 \text { mg/kg/bw Cipro }\end{array}$ & $120.80 \pm 4.37^{*}, \mathrm{a}$ & $99.50 \pm 1.82 *$, a & $21.47 \pm 1.19^{*}, \mathrm{a}$ & $19.90 \pm 0.36^{*}, \mathrm{a}$ & $79.40 \pm 4.88^{*}, \mathrm{a}$ \\
\hline $\begin{array}{l}\text { Group V } \\
8 \mathrm{mg} / \mathrm{kg} / \mathrm{bw} \mathrm{AL}+8.57 \mathrm{IU} \text { Vit E }\end{array}$ & $99.42 \pm 2.02 *, \mathrm{~b}$ & $71.89 \pm 2.51^{*}, \mathrm{~b}$ & $26.25 \pm 4.23^{*}$ & $14.38 \pm 0.50^{*}, \mathrm{~b}$ & $58.79 \pm 5.69 *, \mathrm{~b}$ \\
\hline $\begin{array}{l}\text { Group VI } \\
7.14 \mathrm{mg} / \mathrm{kg} / \mathrm{bw} \text { Cipro + 8.57 IU Vit E }\end{array}$ & $98.40 \pm 4.26^{*}, \mathrm{c}$ & $70.96 \pm 1.99 *, c$ & $26.56 \pm 3.11^{*}$ & $14.19 \pm 0.39{ }^{*} \mathrm{c}$ & $57.64 \pm 4.49^{*}, \mathrm{c}$ \\
\hline $\begin{array}{l}\text { Group VII } \\
8 \mathrm{mg} / \mathrm{kg} / \mathrm{bw} \mathrm{AL}+7.14 \mathrm{mg} / \mathrm{kg} / \mathrm{bw} \text { Cipro + } 8.57 \mathrm{IU} \text { Vit E }\end{array}$ & $104.70 \pm 4.54^{*}, \mathrm{~d}$ & $77.03 \pm 3.02 *, d$ & $23.39 \pm 2.27^{*}$ & $15.40 \pm 0.60 * d$ & $65.92 \pm 7.21^{*}, \mathrm{~d}$ \\
\hline
\end{tabular}

Values presented as Mean + Standard Deviation (SD), $\mathrm{n}=5$, AL $=$ Artemether- Lumefantrine, Cipro = Ciprofloxacin. ${ }^{*}=$ significantly different when all the test groups are compared with control Group I ( $\mathrm{p}<$

0.05), $\mathrm{a}$ = significantly different when Group IV is compared to Group II $(\mathrm{p}<0.05), \mathrm{b}=$ significantly different when Group V is compared to Group II ( $p<0.05$ ), $\mathrm{c}=$ significantly different when Group VII is compared to Group III $(\mathrm{p}<0.05)$, $\mathrm{d}=$ significantly different when Group VII is compared to Group IV ( $\mathrm{p}<0.05)$

HDL-Cholesterol = High-Density Lipoprotein Cholesterol; VLDL-Cholesterol = Very Low-Density Lipoprotein Cholesterol; LDL-Cholesterol = Low Density Lipoprotein Cholesterol 
Table 2 Some Biomarkers of Cardiac Function of Male Wistar Rats Administered Artemether-Lumefantrine, Ciprofloxacin and Vitamin E

\begin{tabular}{|c|c|c|c|c|c|}
\hline Grouping/Dosage & $\begin{array}{l}\text { Troponin I } \\
\text { (ng/ml) }\end{array}$ & $\begin{array}{l}\text { Troponin T } \\
\text { (ng/ml) }\end{array}$ & $\begin{array}{l}\text { Creatine Kinase } \\
\text { (U/L) }\end{array}$ & $\begin{array}{l}\text { Lactate } \\
\text { Dehydrogenase (U/L) }\end{array}$ & $\begin{array}{l}\text { Aspartate } \\
\text { Aminotransferase (U/L) }\end{array}$ \\
\hline $\begin{array}{l}\text { Group I } \\
\text { Control }\end{array}$ & $0.32 \pm 0.06$ & $190.50 \pm 11.67$ & $43.40 \pm 3.91$ & $53.50 \pm 4.86$ & $107.60 \pm 3.21$ \\
\hline $\begin{array}{l}\text { Group II } \\
8 \mathrm{mg} / \mathrm{kg} / \mathrm{bw} \mathrm{AL}\end{array}$ & $0.57 \pm 0.12^{*}$ & $210.80 \pm 14.55^{*}$ & $132.40 \pm 11.63^{*}$ & $74.12 \pm 4.40^{*}, \mathrm{a}$ & $129.80 \pm 11.92^{*}$ \\
\hline $\begin{array}{l}\text { Group III } \\
7.14 \mathrm{mg} / \mathrm{kg} / \mathrm{bw} \text { Cipro }\end{array}$ & $0.47 \pm 0.05^{*}$ & $213.10 \pm 19.75^{*}$ & $76.60 \pm 12.38 *$ & $65.18 \pm 3.56^{*}$ & $165.40 \pm 30.67^{*}$ \\
\hline $\begin{array}{l}\text { Group IV } \\
8 \mathrm{mg} / \mathrm{kg} \mathrm{AL}+7.14 \mathrm{mg} / \mathrm{kg} / \mathrm{bw} \text { Cipro }\end{array}$ & $1.33 \pm 0.28^{*}, \mathrm{a}$ & $229.30 \pm 6.61^{*} \cdot \mathrm{a}$ & $152.00 \pm 14.32^{*}, \mathrm{a}$ & $87.74 \pm 3.15^{*}$, a & $236.00 \pm 23.37^{*}, \mathrm{a}$ \\
\hline $\begin{array}{l}\text { Group V } \\
8 \mathrm{mg} / \mathrm{kg} / \mathrm{bw} \mathrm{AL}+\text { of } 8.57 \text { IU Vit E }\end{array}$ & $0.41 \pm 0.06^{*}, \mathrm{~b}$ & $200.70 \pm 12.75^{*}, \mathrm{~b}$ & $110.20 \pm 7.5^{* b}$ & $65.44 \pm 3.13 *, b$ & $112.90 \pm 6.75^{*}, \mathrm{~b}$ \\
\hline $\begin{array}{l}\text { Group VI } \\
7.14 \mathrm{mg} / \mathrm{kg} / \mathrm{bw} \text { Cipro + 8.57 IU Vit E }\end{array}$ & $0.36 \pm 0.03^{*}, \mathrm{c}$ & $177.80 \pm 11.90^{*}, \mathrm{c}$ & $37.00 \pm 13.13^{*}, \mathrm{c}$ & $50.70 \pm 2.10^{*}, \mathrm{c}$ & $93.50 \pm 7.11^{*}, \mathrm{c}$ \\
\hline $\begin{array}{l}\text { Group VII } \\
8 \mathrm{mg} / \mathrm{kg} / \mathrm{bw} \mathrm{AL}+7.14 \mathrm{mg} / \mathrm{kg} \text { Cipro + } 8.57 \text { IU Vit E }\end{array}$ & $0.50 \pm 0.07^{*}, \mathrm{~d}$ & $177.40 \pm 10.68^{*}, \mathrm{~d}$ & $109.20 \pm 8.06^{*}, \mathrm{~d}$ & $61.84 \pm 4.64 *, d$ & $172.70 \pm 15.88^{*}, \mathrm{~d}$ \\
\hline
\end{tabular}

Values presented as Mean \pm Standard Deviation (SD), $\mathrm{n}=5, \mathrm{AL}=$ Artemether- Lumefantrine, Cipro $=$ Ciprofloxacin. ${ }^{*}=$ significantly different when all the test groups are compared with control Group I (p $<$

0.05). $a$ =significantly different when Group IV is compared to Group II ( $p<0.05) . b=$ significantly different when Group V is compared to Group II ( $<<0.05)$, $c=$ significantly different when Group VII is

compared to Group III ( $\mathrm{p}<0.05), \mathrm{d}=$ significantly different when Group VII is compared to Group IV ( $\mathrm{p}<0.05)$ 
Table 3 Weight of the Heart Tissues of Male Wistar Rats Administered Artemether-Lumefantrine, Ciprofloxacin and Vitamin E

\begin{tabular}{|l|c|}
\hline Grouping/Dosage & Heart (g) \\
\hline $\begin{array}{l}\text { Group I } \\
\text { Control (I ml NS) }\end{array}$ & $0.80 \pm 0.07$ \\
\hline $\begin{array}{l}\text { Group II } \\
8 \mathrm{mg} / \mathrm{kg} / \mathrm{bw} \text { AL }\end{array}$ & $0.74 \pm 0.11^{*}$ \\
\hline $\begin{array}{l}\text { Group III } \\
7.14 \mathrm{mg} / \mathrm{kg} / \mathrm{bw} \text { Cipro }\end{array}$ & $0.62 \pm 0.10^{*}$ \\
\hline $\begin{array}{l}\text { Group IV } \\
8 \mathrm{mg} / \mathrm{kg} \mathrm{AL}+7.14 \mathrm{mg} / \mathrm{kg} / \mathrm{bw} \text { Cipro }\end{array}$ & $0.60 \pm 0.10^{*}$ \\
\hline $\begin{array}{l}\text { Group V } \\
8 \mathrm{mg} / \mathrm{kg} / \mathrm{bw} \text { AL }+8.57 \mathrm{IU} \text { Vit E }\end{array}$ & $0.78 \pm 0.11^{*}$ \\
\hline $\begin{array}{l}\text { Group VI } \\
7.14 \mathrm{mg} / \mathrm{kg} / \mathrm{bw} \text { Cipro }+8.57 \text { IU Vit E }\end{array}$ & $0.64 \pm 0.13^{*}$ \\
\hline $\begin{array}{l}\text { Group VII } \\
8 \mathrm{mg} / \mathrm{kg} \mathrm{AL}+7.14 \mathrm{mg} / \mathrm{kg} / \mathrm{bw} \text { Cipro }+8.57 \mathrm{IU} \text { Vit E }\end{array}$ & $0.64 \pm 0.15^{*}$ \\
\hline
\end{tabular}

Values presented as Mean \pm Standard Deviation (SD), $\mathrm{n}=5, \mathrm{AL}=$ Artemether-Lumefantrine, Cipro = Ciprofloxacin; ${ }^{*}=$ significantly different when all the test groups are compared with control $(\mathrm{p}<0.05)$.

\section{Discussion}

Malaria remains one of the most endemic diseases in the tropics. Di or poly treatments of ailments is a common practice especially in places where there is accessibility to drugs for such ailments, with or without proper laboratory investigations. Malaria and typhoid fever are two common febrile illnesses that are commonly treated concomitantly, perhaps because of ignorance or because of the poor sanitary conditions associated with the sub-tropical region of the world where these two diseases are very prevalent. It is therefore a common practice for ACTs to be administered with antibiotics such as ciprofloxacin for the treatment of malaria whether or not there is confirmed existence of typhoid fever. Multiple drugs administration has been reported to have some harmful effects generally and critically impact body organs [13]. It can also alter biochemical parameters, thereby resulting in harmful effects to the body.

The present study revealed that concomitant administration of artemether-lumefantrine and ciprofloxacin to adult male Wistar rats caused significant increase in the cardiac markers (Lipid profile, Troponin I and T concentrations, activities of CK, LDH and AST). The significant differences may be attributed to drug interactions or synergism in the drugs action. All serum lipid profile parameters recorded significant increases compared to control exception of HDL-cholesterol for Group IV which showed significant reduction compared to control. This finding is in agreement with the findings of Nkereuwen et al., [17] who reported a reduction in serum HDL-cholesterol concentration following the administration of Artemether.

Studies have confirmed that the free and esterified cholesterol accumulates both in the aorta, coronary arteries and cerebral veins $[18,19,20,21]$. Also, high concentration of total cholesterol is an indication of coronary heart disease (CHD) [21]. The increased concentration of cholesterol observed in Group IV compared with the control group suggest that the concomitant administration of artemether-lumefantrine and ciprofloxacin may have induced hypercholesterolemia. This effect was however observed to be significantly reduced when Group VII which received Vitamin E with artemether-lumefantrine and ciprofloxacin concomitantly was compared with Group IV that received artemether-lumefantrine and ciprofloxacin only. The significant decrease maybe attributed to the free radical mop up activity of vitamin E. Studies have shown that certain isomers of vitamins E serve as a protective antioxidant that fights cholesterol oxidation [22]. Tocotrienol isomers of vitamins $E$ have three double bonds that positively impact cardiovascular health due to their ability to reduce the activity of the enzyme that controls cholesterol production/synthesis (called HMG-COA reductase). Tocotrienol isomers can also prevent cell adhesion and therefore slow down progression of atherosclerosis, or hardening/thickening of the arteries [22]. 
There was observed significant increase in the concentrations of triacylglyceride, VLDL- cholesterol and LDLcholesterol in all the test groups compared with the control, with the highest concentration in Group IV that was administered artemether-lumefantrine and ciprofloxacin. The increased concentration was ameliorated in Group VII following the co-administration of vitamin E. The HDL-cholesterol concentration depicted a pattern reduction in the entire test compared with the control. However, the reduction of HDL-c following concomitant administration of artemether-lumefantrine and ciprofloxacin in Group IV was significant compared with the control. The effect was also remediated in Group VII that received vitamin E in addition to artemether-lumefantrine and ciprofloxacin. Significant increase in TG, VLDL, LDL and decrease in HDL is an indication of an unfavorable lipid modification and may result in the formation of atherosclerotic plaques. Reverse cholesterol transport from the peripheral tissues to the liver, where it is excreted, is carried out by HDL-cholesterol and decrease concentration of HDL-cholesterol with high concentration of triglyceride are associated with increased risk of coronary heart disease and ischaemic stroke [23].

The ratio of LDL/HDL is suggested as an index of risk of CHD [24]. Studies confirm that treatments associated with increase in HDL-cholesterol are associated with low risk of CHD and significant regression of arterial lesions. This study is in line with Etim et al. [25] who reported that co-administration of chloroquine phosphate and cefuroxime axetil tends to raise serum LDL-cholesterol level and with Nna et al., [26] who also reported significantly increase concentration of LDL-cholesterol following coartem (artemether-lumenfantrine) administration for 7 days in albino Wistar rats. Very low-density lipoproteins are rich in TG. Elevated VLDL concentrations result in hypertriacylglycerolemia that may give rise to atherosclerosis [27, 20, 28]. Ukpanukpong et al. [29], reported significant increase in VLDL-cholesterol level following administration of pefloxacin. However, Nna et al. [26], reported an insignificant difference in VLDL-cholesterol following coartem and chloroquine administration for 3 and 7 days respectively.

In this study, positive modulatory effect for these lipid parameters was observed in Group VII that receive artemetherlumefantrine, ciprofloxacin and vitamin E concomitantly. Studies have shown that ingesting antioxidant helps in minimizing free radical exposure and reduce oxidative stress [30]. This may explain the effect that was observed when Vitamin E was administered along with the drugs.

Troponin, a trimetric regulatory protein complex consisting of troponin C, troponin I and troponin T, is very necessary for muscle contraction in cardiac and skeletal muscles. They have absolute myocardial tissue specificity [31]. Cardiac Troponin I and T was observed to significantly increase following the concomitant administration of artemetherlumefantrine and ciprofloxacin. An increase troponin concentration indicates cardiac injury, acute coronary injury, acute perimyocarditis, acute pulmonary embolism, acute heart failure and tachycardia [31]. The significant increase in test groups compare to control may be an indication of myocardial infarction and is in line with the findings of Amsterdam et al. [21]. WHO [32], also reported similar results that some antimalarial have been associated with prolongation of the QT interval on the electrocardiogram. Cardiotoxicity is a well-known side effect of several cytotoxic drugs, especially of the anthracyclines and can lead to long term morbidity [19].

In this study, the suspected toxicity induced by the concomitant administration of artemether-lumefantrine and ciprofloxacin may have been combatted by vitamin $\mathrm{E}$, as there was observed significant reduction in the concentration of both Troponin I and T in Group VII compared with Group IV. The same effect was observed when Group VI that received ciprofloxacin with vitamin E was compared with Group III that had ciprofloxacin only. These results further suggest that vitamin E may have prevented mitochondrial dysfunction. Reports by Wallace and Starkozy [33], Wallace [34] and Sardao et al. [35] states that due to the abundance of mitochondria in cardiomyocytes and the close relationship linking oxidative metabolism with myocardial function and viability, mitochondrial dysfunction is usually considered as a prime suspect in cardiotoxicity, especially when cardiomyocyte survival is compromised.

Creatine kinase resides in the cytosol and facilitates high energy phosphates into and out of mitochondria. It is distributed in a number of tissues including heart and skeletal muscle. Elevated concentration of creatine kinase is an indicator of cardiac problems such as myocardial infarction, myositis, myocarditis and rhabdomyolysis [36]. There was significant increase in the concentration of creatine kinase in all the test groups compared with the control. The result is in agreement with the report by Young [37] who documented increase in serum level of CK following the administration of a wide variety of drugs. Sathasivam and Lecky [38]; Lee [39]; Bannwarth [40] and WHO [32] also reported increase in serum CK activity in response to drugs. The increase activity of CK observed in this study was ameliorated with co-administration of vitamin E, further supporting its antioxidant role.

Lactate dehydrogenase (LDH) plays an important role in human body by catalyzing the conversion of pyruvate to lactate. LDH-1 isozyme is normally found in the heart muscle, liver, muscles, kidney, lungs, erythrocytes and LDH-2 suggests myocardial infarction [18]. Under normal condition, LDH is produced in human body in little amounts with low monitory value. However, many factors have been reported to increase LDH levels in the blood stream such as 
ascites, allergy and drugs; prolong exercise and severity of preeclampsia [41]. There was significant increase in the concentration of serum LDH in this study when all the test groups were compared with the control. This effect was also ameliorated when vitamin $\mathrm{E}$ was combined in the treatment regimen. Al-faris et al. [42] reported increases in ALT, AST, CK-MB and LDH activities following ciprofloxacin treatment. Artemether-lumefantrine has also been reported to increase blood LDH, bilirubin, total protein and haemolytic anaemia (Consumer/Non-Health Professional, USA, 2012). Elevated concentration of LDH may therefore be an indication of myocardial infarction.

Aspartate aminotransferase (AST) is an enzyme found in the cells throughout the body but mostly in the heart and liver, to a lesser extent in red blood cells, muscle tissue and other organs, such as the pancreas and kidneys [43]. An injury to any of these tissues may elevate its blood level and damaged to the heart or liver cells, may release AST from the cells into the peripheral blood [43]. Significant increase in serum AST concentration was observed in all the treated groups compared to the control. This finding is line with Minuk et al. [44]; Hirsh and Lundquist [45]; Akpanyung et al. [46]; and Ugokwe et al. [47], who reported increased concentration of serum AST in response to antimalarials and antibiotics. The significant increase in AST concentration observed in this study maybe an evidence of drug induced toxicity and may be as a result of leakage from the cells through peroxidative damage of membranes and loss of functional integrity of cellular membrane in liver as reported by Iniaghe et al. [48]. The effect was significantly reduced with coadministration with vitamin E. Little et al. [6] and Ukwenya et al. [7] suggested that the generation of free radicals depletes the antioxidant defense system causing oxidative stress following administration of artemether-lumefantrine. The findings of Nwachukwu et al. [49], that essential vitamins such as vitamin E, vitamin C or folic acid may play potential harmful roles by exacerbating malaria episodes or interfere with antimalarial therapy however does not agree with the present findings. This is therefore a subject for further research.

Changes in cardiac weight is an in index of drug- induced cardiotoxicity. The degree of toxicity of any drug or organ can be ascertained with the relative weight of organ [50]. The weight of the heart was significantly decreased following the drug (ACT) administration singly and combined (ACT and Cipro) compared with the control. The observed effect was improved with concomitant administration of the drugs combination with vit E. Otuechere et al. [51] reported a reduction in the weight of heart tissue following the administration of Artemether-Lumefantrine and Artesunate amodiaquine. A reduction in the heart/body weight ratio in rats administered ciprofloxacin was also reported by Obaleye et al. [52]. However, cardiac weight was reported to increase following the administration of artesunate, a monotherapy for malaria [53]. The observed reduction in the weight of the heart in this study may be as a result of interaction by the two drugs and possible generation of free radicals. Metabolism of drugs are known to generate free radicals and the abundance of free radicals leads to oxidative stress which may cause death of cardiac muscles [53]. The reduction in heart weight coupled with increase concentration of troponin in this study suggest that concomitant administration of artemether-lumefantrine and ciprofloxacin may be cardiotoxic. The effect was improved with concomitant treatment of the drugs combination with vitamin E. Vitamin E is a potent antioxidant which is able to interact and scavenge free radicals from the system and reduce their deleterious effect.

\section{Conclusion}

The findings of this study generally suggest that Concomitant administration of Artemether-Lumefantrine and ciprofloxacin may induce cardio-toxicity in male rats. Co - administration of the drugs with vitamin E, reduced the observed effects, suggesting its role as an antioxidant.

\section{Compliance with ethical standards}

\section{Acknowledgments}

The technical contributions by Mr Nsikan Malachy of the Department of Pharmacology and Toxicology, University of Uyo, Uyo and Bridge Biotech Laboratory, Ilorin are acknowledged.

\section{Disclosure of conflict of interest}

There is no conflict of interest among the authors.

\section{Statement of ethical approval}

Ethical approval for the study was obtained from the Research Ethical Committee of the Faculty of Basic Medical Sciences, University of Uyo, Uyo, Akwa Ibom State, Nigeria. 


\section{References}

[1] WHO (World Health Organization) Economic cost of malaria. Roll back malaria program report. 2008.

[2] Eneanya CI. Seasonal variation in malaria episodes among residents of Udi, a semi-urban community in Southeast Nigeria. Nigerian Journal of Parasitology. 1998; 19(1): 39 - 43.

[3] Caraballo H. Emergency department management of mosquito-borne illness: Malaria, dengue and West Nile virus. Emergency Medicine Practice. 2014; 16: 5 - 11.

[4] Federal Ministry of Health (FMH). Federal Ministry of Health. A road map for malaria control in Nigeria, a bridged version, Abuja. Strategic Plan, 2009-2013, Yahian Press Ltd. 2010; 155.

[5] WHO (World Health Organization). Guidelines for the treatment of malaria. Geneva: WHO. 2015.

[6] Little RJ, Pestano AA, Parra Z. Modeling of peroxide activation in Artemisinin derivatives by serial docking. Journal of Molecular and Modeling. 2009; 15: 847 - 857.

[7] Ukwenya VO, Tijani AS, Sodunke GA, Fakunle JB. Acute administration of co-artesiane induces oxidative stress in the testes of adult male Wistar rats. Bioscience Research and Communication. 2010; 22(5): 259 - 265.

[8] Kalra SP, Naithani N, Mehta SR, Swamy AJ. Current trends in the management of typhoid fever. Armed Forces Indian Medical Journal. 2003; 59: 130 - 135.

[9] Olcay E, Neytemur 0, Kaleagasioglu F. Oral toxicity of Pefloxacin, Norfloxacin, Ofolaxcin and Ciprofloxacin. Comparison of biochemical and histopathological effects of achilles tendon in rats. Journal of Toxicological Science. 2011; 36(3): $339-345$.

[10] Alhassan HM, Shidali NN, Managa SB, Abdullahi K, Hamid KM. Co-infection profile of Salmonella typhi and malaria parasite in Sokoto- Nigeria. Global Journal of Science, Engineering and Technology. 2012; 2(201): 13 - 20.

[11] Uwah AF, Ndem JI, Akpan EJ. Combining Artesunate-Amodiaquine and Ciprofloxacin improves serum lipid profile of mice exposed to Plasmodium berghei. International Journal of Biomedical Research. 2014; 5(8): 487 - 489.

[12] Sharma B, Matlani M, Gaind R, Pandey K. Malaria and Typhoid co-infection in India: A Diagnostic Difficulty. Journal of Dental and Medical Science. 2016; 15(9): 101 - 104.

[13] Croft AM, Whitehouse DP, Cook GC, Beer MD. Safety evaluation of the drugs available to prevent malaria. National Library of medicine. 2002; 1(1): 19 - 27.

[14] Baxter K. (Ed). Stockley's Drug Interactions. London: Pharmaceutical press. 2010.

[15] Ojewole JAO. Drug Interactions In: Therapeutic Basis of Clinical Pharmacy In The Tropics, Third edition. Enugu: SNAAP press. $2004 ; 21-42$.

[16] Friedwald WT, Levy RI, Fredrickson DS. Estimation of concentration of low-density lipoprotein cholesterol in plasma without use of the preparative ultracentrifuge. Clinical Chemotherapy. 1972; 18: 499 - 502.

[17] Nkereuwen E, Paul 00, Elias A. Effect of Artemether treatment on plasma lipid profile in malaria. Pharmacology and Pharmacy. 2014; 5: 646 - 656.

[18] Rao SP, Miller S, Rosenbaum R, Lakier JB. Cardiac troponin I and cardiac enzymes after electrophysiologic studies, ablations, and defibrillator implantations. American Journal of Cardiology. 1999; 43: 467 - 475.

[19] Schimmel KJ, Richel DJ, Van den Brink RB, Guchelaar HJ. Cardiotoxicity of cytotoxic drugs. Cancer Treatment Review. 2004; 30(2): 181 - 191.

[20] Do R, Willer CJ, Schmidt EM, Sengupta S, Gao C, Peloso GM, Gustafsson S, Kanoni S, Gann AA, Chen J. Common variants associated with plasma triglycerides and risk for coronary artery disease. Nature Genetics. 2013; 45: $1345-1352$.

[21] Amsterdam EA, Wenger NK, Brindis RG, Casey DE, Ganiats TG, Holmes C. AHA/ACC Guideline for the Management of Patients with Non-ST-Elevation Acute Coronary Syndromes: A Report of the American College of Cardiology/ American Heart Association Task Force on Practice Guidelines. Journal of American College of Cardiology. 2014; 64(24): 2654 - 2687.

[22] Shekelle PGM, Morton SC, Jungvig LK, Udani J, Spar M, Tu WJ, Coulter I, Newberry SJ, Hardy M. Effect of supplemental vitamin $\mathrm{E}$ for the prevention and treatment of cardiovascular disease. International Journal of General Medicine. 2004; 19(4): 380 - 389. 
[23] Marz W, Kleber ME, Scharnagl H. HDL-cholesterol: reappraisal of its clinical relevance. Clinical Research and Cardiology. 2017; 106(9): 663-75.

[24] Nicholis SJ, Tuzcu EM, Sipahi I, Grasso AW, Schoehagen P, Hu T, Wolski K, Crowe T, Desai MY, Hazen SL, Kapadia SR, Nissen SE. Statins, high-density lipoprotein cholesterol and regression of coronary atherosclerosis. The Journal of American Medical Association. 2007; 297: 499 - 508.

[25] Etim OE, Akpan EJ, Akpanabiatu MI. Effect of co-administration of chloroquine and cefuroxime axetil on serum lipids and lipid peroxidation in albino Wistar rats. International Journal of Biochemistry, Bioinformatics and Biotechnology studies. 2018; 3(1): 15 - 20.

[26] Nna VU, Ofemi OE, Archibong AN, Bassey SC. Alteration in serum lipid profile following separate administration of antimalarial drugs (coartem and chloroquine): A comparative study. Der Pharma Chemica, 2014; 6(4): 415 421.

[27] Thomsen M, Varbo A, Tybjaerg-Hansen A, Nordestgaard, BG. Low non-fasting triglycerides and reduced all-cause mortality: A mendelian randomization study. Clinical Chemistry. 2014; 60: 737 - 746.

[28] Johansen CT, Hegele RA. Using Mendelian randomization to determine causative factors in cardiovascular disease. Journal of International Medicine. 2013; 273: 44 - 47.

[29] Ukpanukpong RU, Eteng MU, Dasofunjo K. Antioxidant interactions of pefloxacin, garlic, vitamins C and E on lipid profile level of albino Wistar rats. Journal of Applied Pharmaceutical Science. 2013; 3(3): 167 - 170.

[30] Stocker R, Keaney JF. Role of oxidative modifications in atherosclerosis. Physiology Reviews. 2004; 84: 1381 1478.

[31] Vasudevan DM, Sreekumari S, Kannnan V. Textbook of Biochemistry for Medical Students, Seven edition. 2013; $301-310$.

[32] WHO (World Health Organization). The cardiotoxicity of Antimalarials: Report of the WHO evidence review group. Geneva. Switzerland. 2016.

[33] Wallace KB, Starkov AA. Mitochondrial targets of drug toxicity. Annual Reviews in Pharmacology and Toxicology. $2000 ; 40: 353-388$.

[34] Wallace KB. Mitochondrial target of drug therapy. Trends in Pharmacological Sciences Journal. 2008; 29: 361366.

[35] Sardao VA, Pereira SL, Oliveira PJ. Drug induced mitochondrial dysfunction in cardiac and skeletal muscle injury. Expert Opinion on Drug Safety. 2008; 7(2): 129 - 146.

[36] Brewster LM, Coronel CM, Sluiter W, Clark JF, van Montfrans GA, Saks, V. (ed.). Ethnic differences in tissue creatine kinase activity: An observational study. PLOS one. 2012; 7(3): 32471.

[37] Young DS. Effects of drugs on clinical laboratory tests, third edition. Washington DC: AACC press. $1990 ; 120$ 122.

[38] Sathasivam S, Lecky B. Statin induced myopathy. Biomedical Journal. 2008; 337(3): 22 - 86.

[39] Lee A. Adverse drug reactions. Second edition, Great Britain Pharmaceutical Press. 2009.

[40] Bannwarth B. Drug-induced myopathies. Expert Opinion on Drug Safety. 2002; 1(1): 65 - 70.

[41] Pandit A, Sachdeva T, Bafna P. Drug-induced hepatotoxicity: A review. Journal of Applied Pharmacological Science. 2012; 2(5): 233 - 243.

[42] Al-faris OJ, Al-Shawi NN, Kako MD. Possible cardiac adverse effects induced by therapeutic doses of Ciprofloxacin in Juvenile rats. Iraqi Journal of Pharmaceutical Science. 2012; 21: 2.

[43] Dufour DR, Lott JA, Nolte FS, Gretch DR, Koff RS, Seeff LB. Diagnosis and screening, diagnosis and monitoring. Clinical Chemistry. 2000; 46(12): 2027 - 2049.

[44] Minuk WS, Vaher D, Vogelstein B. The Metabolic and Molecular Bases of Inherited Diseases. 8th Edition. New York. 2005; 5313 - 5329.

[45] Hirsh A, Lundquist IB. Therapeutic effects of Ciprofloxacin on the pharmacokinetics of Carbamezepine in healthy adult. Journal of Pharmaceutics. 2009; 24(1): 63 - 68. 
[46] Akpanyung EO, Bassey UE, Usoh IF, Iba IU. Effect of Combined Administration of Artequin $囚$ and Pefloxacin on some Indices of Liver and Renal Functions of Male Albino Wistar Rats. Pharmacologyonline. 2015; 3: 84 - 90.

[47] Ugokwe CU, Awobode HO. Alterations in water quality, enzyme levels and haematology of oreochromisniloticus (Nile tilapia) from River Ogun at Abeokuta Nigeria. International Research Journal of Environmental Sciences. 2015; 4(10): 1 - 9 .

[48] Iniaghe OM, Malomo SO, Adebayo JO. Hepatoprotective effect of the aqueous extract of leaves of Acalypha racemosa in carbon tetrachloride treated rats. International Research Journal of Plant Science. 2008; 2: 301 305.

[49] Nwachukwu NF, Mishra M, Marcelle T, Owolabi JB. Effects of vitamins in Augmentation of malaria treatment: A review. Asian Pacific Journal of Health Sciences. 2016; 3(4): 34 - 43.

[50] Lazic SE, Semenova E, Williams DP. Determining organ weight toxicity with Bayesian causal models: Improving on the analysis of relative organ weights. Scientific Report. 2020; 10: 6625.

[51] Otuechere CA, Edewor G, Kale OE, Ekor M. Subacute Therapeutic Dosing of Artemether-Lumefantrine and Artesunate-Amodiaquine Combination Preserves Plasma Cholesterol, Renal Antioxidant Status, and Organ Weights in Rats. Malaria Research and Treatment. 2012; 1 - 5.

[52] Obaleye JA, Akinremi CA, Balogun EA, Adebayo JO. Toxicological Studies and Antimicrobial Properties of some Iron (III) Complexes of Ciprofloxacin. African Journal of Biotechnology. 2007; 6(24): 2826 - 2832.

[53] Ajibade AJ, Fakunle PB, Adewusi MO, Oyewo 00. Some Morphological Findings on the Heart of Adult Wistar Rats Following Experimental Artesunate Administration. Current Research in Cardiovascular Pharmacology. 2012; 1(1): $1-9$. 